\title{
VOLCANIC ASH LAYERS IN BARE ICE AREAS NEAR THE YAMATO MOUNTAINS, DRONNING MAUD LAND AND THE ALLAN HILLS, VICTORIA LAND, ANTARCTICA
}

\author{
by \\ Fumihiko Nishio, \\ (National Institute of Polar Research, 9-10, Kaga 1-chome, Itabashi-ku, Tokyo 173, Japan) \\ Takayoshi Katsushima \\ (Department of Geology and Mineralogy, Hokkaido University, Kita-10, Nishi-8, Kita-ku, \\ Sapporo 060, Japan) \\ and Hirokazu Ohmae \\ (Institute of Low Temperature Science, Hokkaido University, Kita-19, Nishi-8, Kita-ku, \\ Sapporo 060, Japan)
}

\section{ABSTRACT}

Dirt layers of tephra were found on the bare ice surface in the Meteorite Ice Field near the Yamato Mountains, Dronning Maud Land, and near the Allan Hills, Victoria Land, Antarctica. The grain-size analyses of volcanic ash fragments show that the mean grain size in the Allan Hills region is larger than that in the Yamato Mountains region. This fact indicates that the volcanic sources of the dirt layers in the Yamato Mountains region are farther away than those in the Allan Hills. Their constituent fragments are well-sorted and composed mainly of volcanic glass shards with minor amounts of crystal fragments.

Glass shards of the tephra from the Yamato Mountains region have a composition of tholeiitic andesite which is low in alkali and high in iron but not so enriched in titanium, and the associated crystal fragments consist of calcic plagioclase, subcalcic clinopyroxene, orthopyroxene and magnetite. The nature of island arc tholeiite of the tephra indicates that its source is some volcano in the South Sandwich Islands.

On the other hand, the tephra from the Allan Hills region is composed of glass shards of trachybasaltic composition and crystal fragments of titanaugite calcic plagioclase, kaersutite, olivine, rhönite and titanomagnetite. A young volcano of the McMurdo volcanic group is suggested as a possible source of this tephra.

\section{INTRODUCTION}

In the Meteorite Ice Field near the Yamato Mountains in Dronning Maud Land and in the bare ice area of the Allan Hills in Victoria Land, Antarctica, many prominent dirt layers occur up-glacier from nunataks. On both bare ice areas a large number of meteorites have been discovered and collected (Yanai 1981). To elucidate the mechanism of accumulation of these meteorites, studies of the ice flows in both bare ice areas were carried out and the occurrences of dirt layers were also described (Nishio and Annexstad 1979). Though the dirt layers dip up-glacier, little is known of their geometry. It was suggested that the dirt layers are probably windblown dust or perhaps even tephra layers.

During the two austral summers of 1978-79 and 1979-80, ice samples containing the dirt layer in the bare ice area of the Allan Hills were collected by the joint U.S. - Japanese meteorite search team (Nishio and Annexstad 1980). In the Meteorite Ice Field near the Yamato Mountains, dirt layers were identified and specimens collected by the glaciological survey party of the 23rd Japanese Antarctic Research Expedition in 1982-83 (Nishio and others 1984).

Based on petrographical studies (Katsushima and others
1984), all samples of dirt layers were found to contain abundant volcanic ash fragments. This fact shows that most of the dirt layers in the bare ice area are tephra layers. Tephra in glacier ice offers great potential as marker levels for stratigraphic studies and should be useful in providing isochronous planes in the ice sheet.

Many tephra layers have also been found in ice cores and on the surface of glaciers in Antarctica. Gow (1963) presented the first report on tephra layers in ice cores of the Ross Ice Shelf drilled at Little America V. In the deep ice core (depth $2164 \mathrm{~m}$ ) at Byrd station, Byrd Land (Fig.1), 25 distinct tephra layers and an estimated 2000 dust bands are preserved (Gow and Williamson 1971). The volcanic source for six tephra layers is studied on the basis of chemical composition of glass shards (Kyle and Jezek 1978, Kyle and others 1981). Large volcanic glass shards were reported by Kyle and others (1981) at $726 \mathrm{~m}$ depth in the Dome $\mathrm{C}$ ice core, which have compositions similar to those analyzed in the Byrd ice core and have the same source in Byrd Land. Volcanic glass shards were also reported by King and Wagstaff (1980) from the $101 \mathrm{~m}$ firn core at South Pole station. Furthermore, a $5 \mathrm{~cm}$ thick dust band at a depth of $100.8 \mathrm{~m}$ in the Vostok ice core has been identified as tephra (Kyle and others 1982). In addition to the known occurrences of tephra layers in Antarctic ice

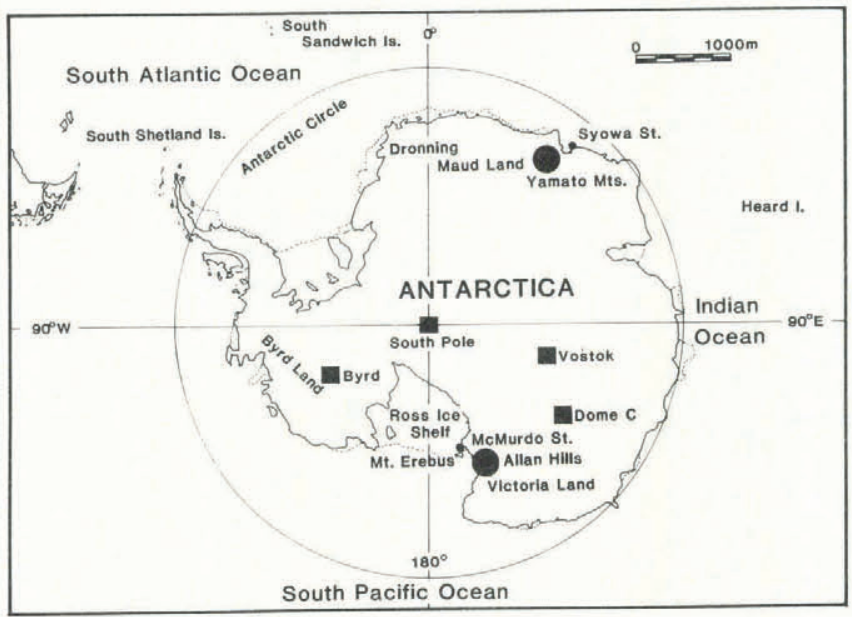

Fig.1. Map of Antarctica showing the location of the Yamato Mountains and the Allan Hills (large solid circles) and indicating sites of four ice cores (solid squares) known to contain tephra layers. 
cores, Keys and others (1977) described the occurrence and compositions of some tephra layers in the ice surface of several glaciers in south Victoria Land.

It is important to study tephra layers found in both bare ice surfaces of the Yamato Mountains and of the Allan Hills because tephra layers offer stratigraphic markers in the ice sheet in correlation between widely spaced ice cores and, if tephra is datable volcanic ash, the tephra layers are isochronous planes in the ice sheet.

In the present paper we describe the occurrence and grain-size analyses of dirt layers found in the bare ice areas near the Yamato Mountains and the Allan Hills. The petrography and the results of chemical analyses obtained by electron probe microanalyser of the constituent materials of each tephra layer in both regions were also described.

\section{OCCURRENCE AND DESCRIPTION OF DIRT} LAYERS

Englacial dirt layers outcropping on the bare ice surface can be observed easily when there is no snow deposited but may be missed when the dirt is in low concentrations. Since albedo decreases locally on the surface of a dirt layer, the ice within the dirt layer ablates faster than the surrounding ice to form narrow shallow troughs (Fig.2). Individual dirt layers showed great differences in length, width, composition of materials and their

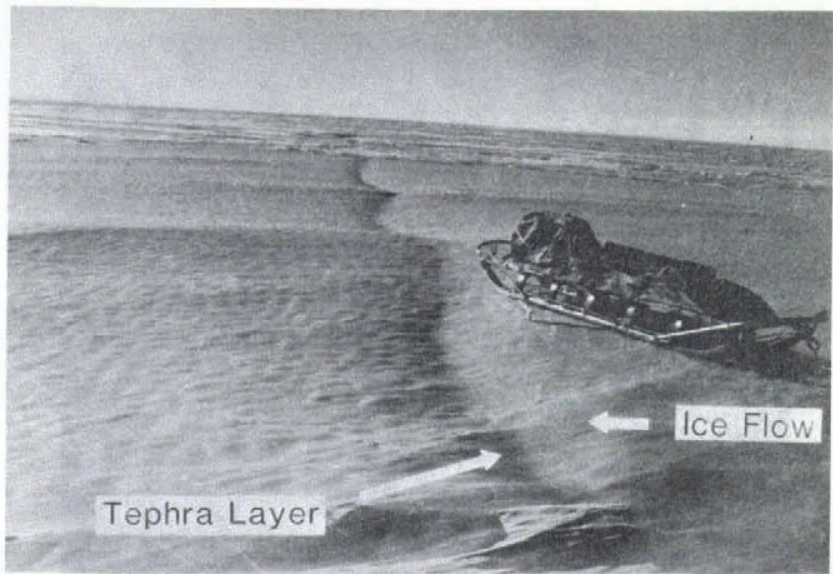

Fig.2. Tephra layers on the bare ice surface in the Allan Hills. Ice flows from right to left.

concentration. Two types of layers are distinguished by the difference in colour tone. The darkest layer is very dark brown to black with a high concentration of materials generally containing pale brown, dirty fragments and devitrified glass shards. The other type of layer is characterized by low concentrations of materials generally containing colourless or pale brown fragments and clear glass shards. The thickness of the dirt layers varies from a few centimetres to about $15 \mathrm{~cm}$, and the layers dip steeply up-glacier. The dirt layers generally have a sharp dirt/ice boundary in the bottom of the dirt layer, whereas in the upper part of the layer it is diffuse.

Comments on occurrences of dirt layers in both areas are given below.

\subsection{Yamato Meteorite Ice Field}

Three of the dirt ice samples were collected from different dirt layers in the Meteorite Ice Field near the Yamato Mountains during triangulation chain surveying to measure glacier movement, as shown in Figure 3. The ice near the Motoi Nunatak flows from south-east to north-west at a velocity of from 0.5 to $1 \mathrm{~m} \mathrm{a}^{-1}$ (Naruse 1978). Glacier movement in the bare ice area, where dirt ice samples were collected, is probably also from south-east to north-west at a velocity of less than several metres per year. Each dirt layer is about $1 \mathrm{~m}$ in width and several centimetres in thickness, and dips gently up-glacier. In Figure 3, both dirt layers of $\mathrm{K}-26(1)$ and $\mathrm{K}-26(2), 1.3 \mathrm{~km}$ apart, are perhaps identical.

\subsection{Allan Hills ice field}

Eight dirt layers containing tephra were found in the bare ice area east of the Allan Hills, as shown in Figure 4.

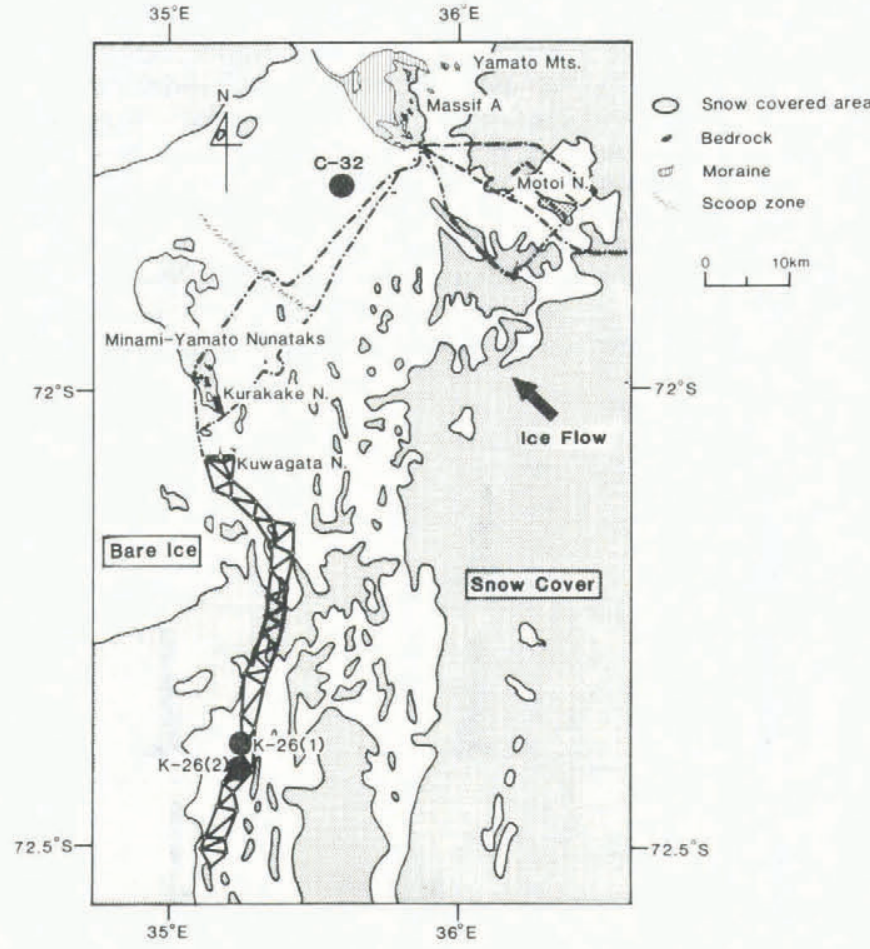

Fig.3. Map of southern part of the Meteorite Ice Field near the Yamato Mountains. Solid circles show the sampling site of dirt ice in the dirt layer, and sample names are given as $\mathrm{C}-32, \mathrm{~K}-26(1)$ and $\mathrm{K}-26(2)$. Solid line indicates the triangulation chain installed on the Kuwagata Nunatak as datum points and extended about $50 \mathrm{~km}$ southward. Dot-dash line shows the traverse route for glaciological study.

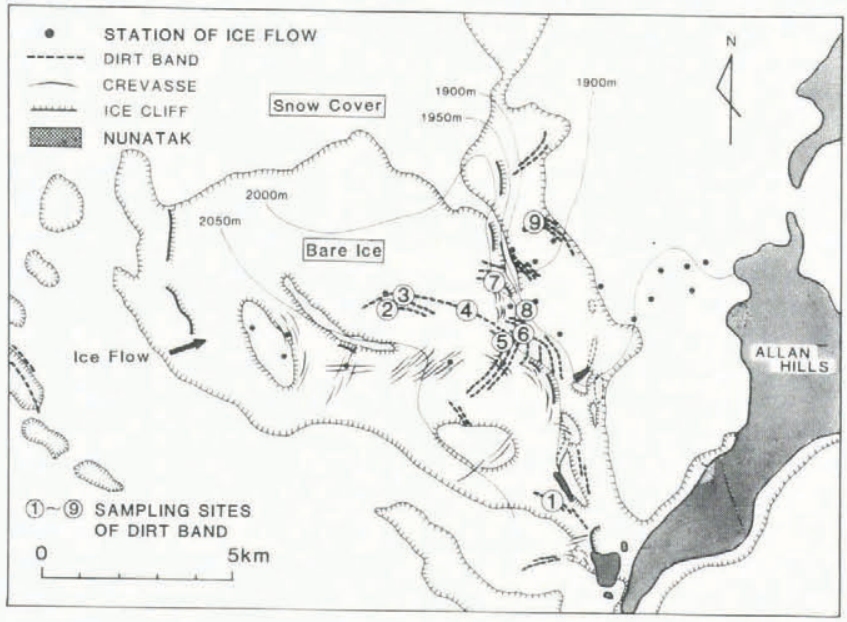

Fig.4. Surface morphology and dirt layer distribution in the bare ice field of the Allan Hills. The open circles with numbers show the location of samples.

Dirt layer 4 was followed for approximately $6 \mathrm{~km}$, and was covered with snow in places. As shown in Figure 2, this layer, $8 \mathrm{~cm}$ in thickness, dips steeply by $16^{\circ}$ up-glacier, and the darkest one contains pale brown devitrified glass shards. Dirt layers 2,3 and 5 are approximately parallel to layer 4 , the closest being $100 \mathrm{~m}$ from layer 3 .

The horizontal velocity of the bare ice was less than $2.5 \mathrm{~m} \mathrm{a}^{-1}$ and the velocity vector points principally north-east, which is perpendicular to the contour lines (Nishio and Annexstad 1980). As can be seen in Figure 4, most of the dirt layers are oriented perpendicular to the glacier flow, but in places they are parallel to it. The most remarkable layer is 4 , which shows a U-shaped surface configuration, thrusted by the upward glacial flow. 


\section{GRAIN SIZE OF VOLCANIC ASH FRAGMENTS}

The grain-size distribution of these tephra layers has been determined by scanning electron microphotography, in which the cross-sectional area of the irregular shape of volcanic ash fragments is estimated by the area of the circle and then the grain size is given as the particle diameter, the same as the area of circle shape. The grain-size distribution is shown as histograms in Figure 5 for three tephra layers in the Meteorite Ice Field and eight, designated ALH, in the bare ice area of the Allan Hills. Grain size is shown on a logarithmic scale in units of phi and $u \mathrm{~m}$.
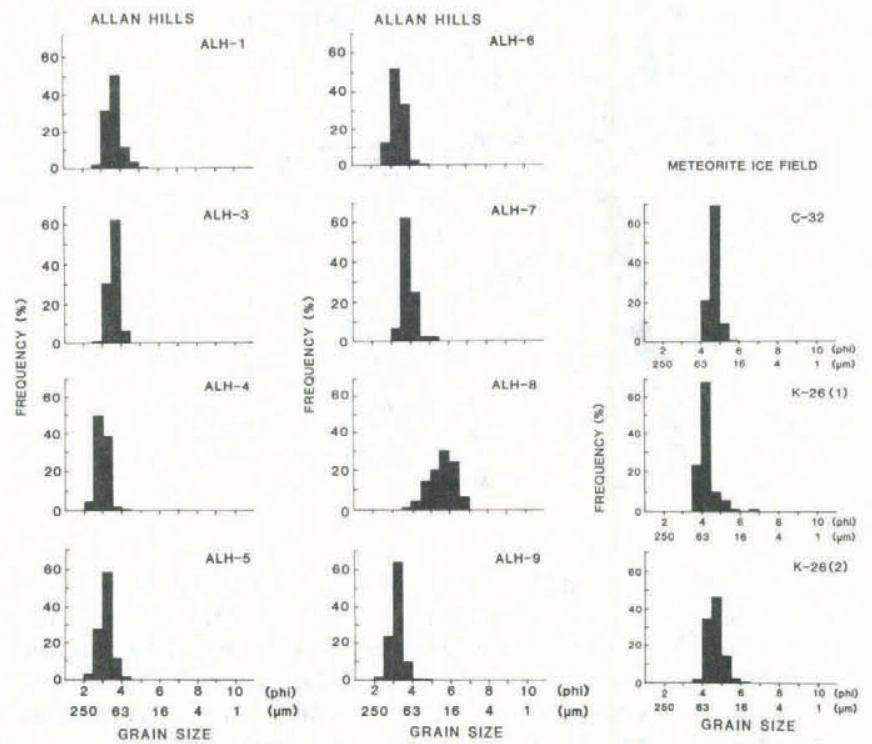

Fig.5. Histograms of grain-size distribution for three tephra layers in the Meteorite Ice Field and eight, designated $A L H$, in the bare ice of the Allan Hills area. The percentage of particles of each grain-size interval was computed assuming a circular cross-section for the particles. Note that the size is logarithmic, in units of phi and $\mu \mathrm{m}$.

All the tephra layers show normal grain-size distribution. Apart from ALH-8, the samples in the Allan Hills have a strong indication of unimodality with median grain size of from 128 to $69 \mu \mathrm{m}$, whereas ALH-8 shows broadly normal distribution with median grain size of 19 $\mu \mathrm{m}$. The samples in the Meteorite Ice Field also have a strong normal distribution with median grain size of from 55 to $40 \mu \mathrm{m}$. The nature of the distribution is probably a function of the distance from the volcanic source and the eruption size. Carey and Sigurdsson (1982) and Cornell and others (1983) have shown that generally the mean grain size of deposited volcanic ash decreases with increasing distance from volcanic source. Also, the grain-size distribution near the eruption centre is bimodal, whereas distal samples are unimodal in grain size from analyses of ash layers in deep-sea cores and ashfall deposited after the eruption of Mount St Helens. The larger grains of ash are due probably to the shorter distance of transport. As can be seen in Figure 5, the mean grain sizes in the Allan Hills are larger than those in the Meteorite Ice Field. Therefore, it is suggested that the volcanic sources of tephra layers in the Meteorite Ice Field are farther away than those in the Allan Hills.

\section{PETROGRAPHY OF TEPHRA}

4.1. Yamato Meteorite Ice Field

The dirt layer in the bare ice of the Meteorite Ice Field near the Yamato Mountains contains abundant fine fragments which are well-sorted and composed predominantly of glass shards, with minor quantities of crystal fragments such as plagioclase, clinopyroxene, orthopyroxene and opaque minerals. Glass shards are obviously volcanic. Most of the crystal fragments carry adherent glass, indicating that they are of volcanic origin.
TABLE I. MODAL COMPOSITIONS OF THE FRAGMENTAL MATERIAL IN THE DIRT LAYERS*

Locality

Yamato ash

Allan ash

Glass shards

85.5

Crystal fragments:

plagioclase

$9.7(7.0)$

clinopyroxene

$3.3(2.4)$

orthopyroxene

$1.2(0.9)$

olivine

amphibole

others

0.3

$6.9(4.6)$

$10.1(5.5)$

$4.1(2.1)$

$3.9(1.0)$

2.2

Glass shards + crystals with adherent glass/total fragmental material

95.8

* Figures in parentheses indicate modal composition of crystal fragments with adherent glass.
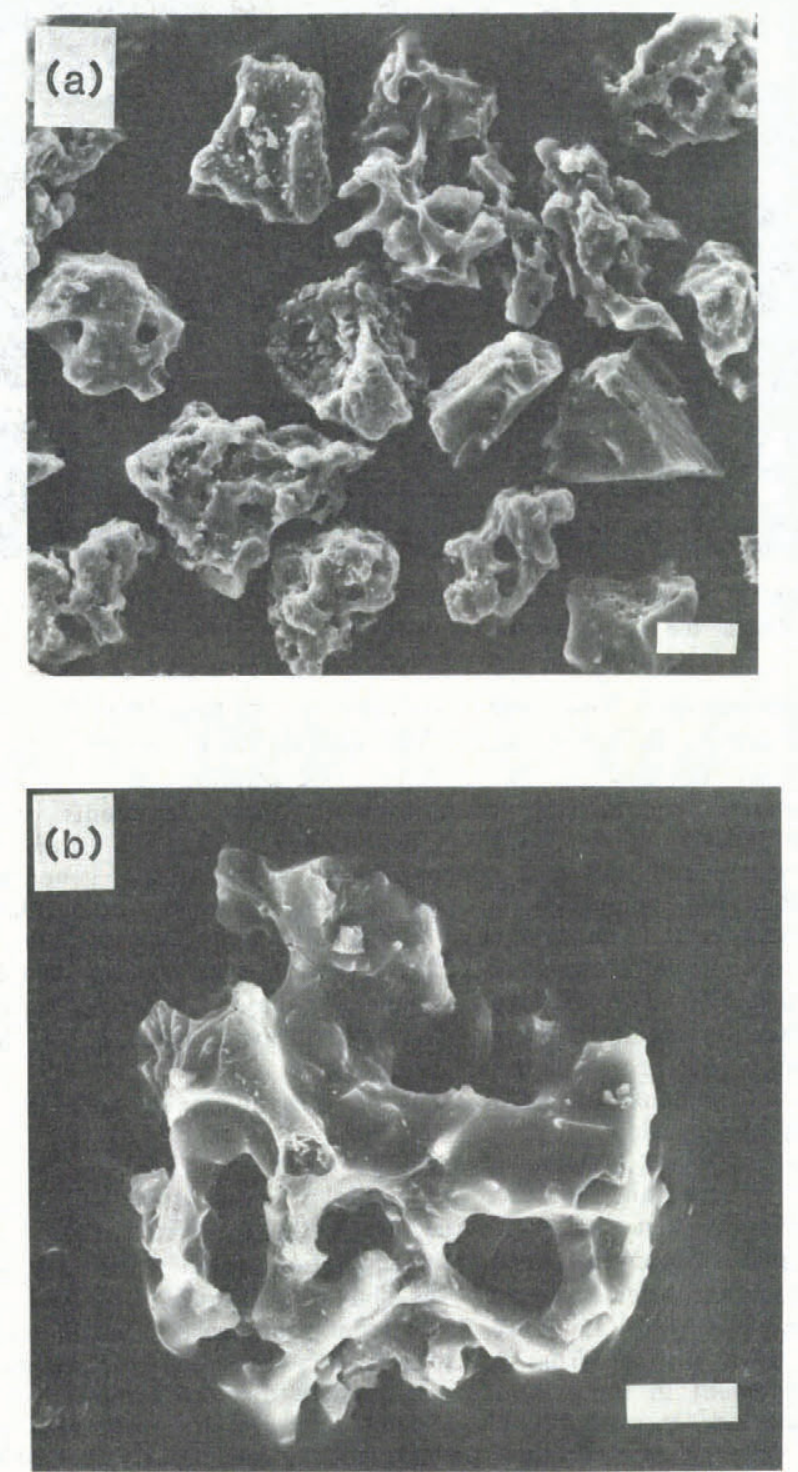

Fig.6. Scanning electron microphotographs of the volcanic ash from the dirt layer in the Yamato Meteorite Ice Field. (a): Highly vesicular glass shards and two crystal fragments at centre right. The scale is $20 \mu \mathrm{m}$. (b): A highly vesicular glass shard. The scale is $10 \mu \mathrm{m}$. 
The fragments identified as volcanic ash under the microscope exceed $95 \%$ of the total (Table I).

Glass shards are characteristically angular and highly vesicular, and include crystallites and, rarely, microlites (Fig.6).

Crystal fragments occur with or without adherent glass. Orthopyroxene and clinopyroxene are generally slender prismatic crystals. Orthopyroxene shows faint pleochroism of light yellowish-green. whereas clinopyroxene is light yellowish-green, free from pleochroism. Plagioclase is colourless and subhedral to anhedral. Magnetite occurs as euhedral crystals in some glass shards.

\subsection{Allan Hills ice field}

The dirt layer in the bare ice area near the Allan Hills also includes abundant fine fragments which are well-sorted and composed mainly of glass shards and subordinate amounts of crystal fragments (Table I). Therefore, most of them are also identified as volcanic ash. However, the deposits are slightly larger in size and have more abundant crystal fragments than those of the Yamato Meteorite Ice Field.

Glass shards are pale brown to cloudy dark brown and include microlites and crystallites. They are generally poor in vesicularity, and their vesicle walls and surfaces are relatively smooth. Some of the glass shards contain a large
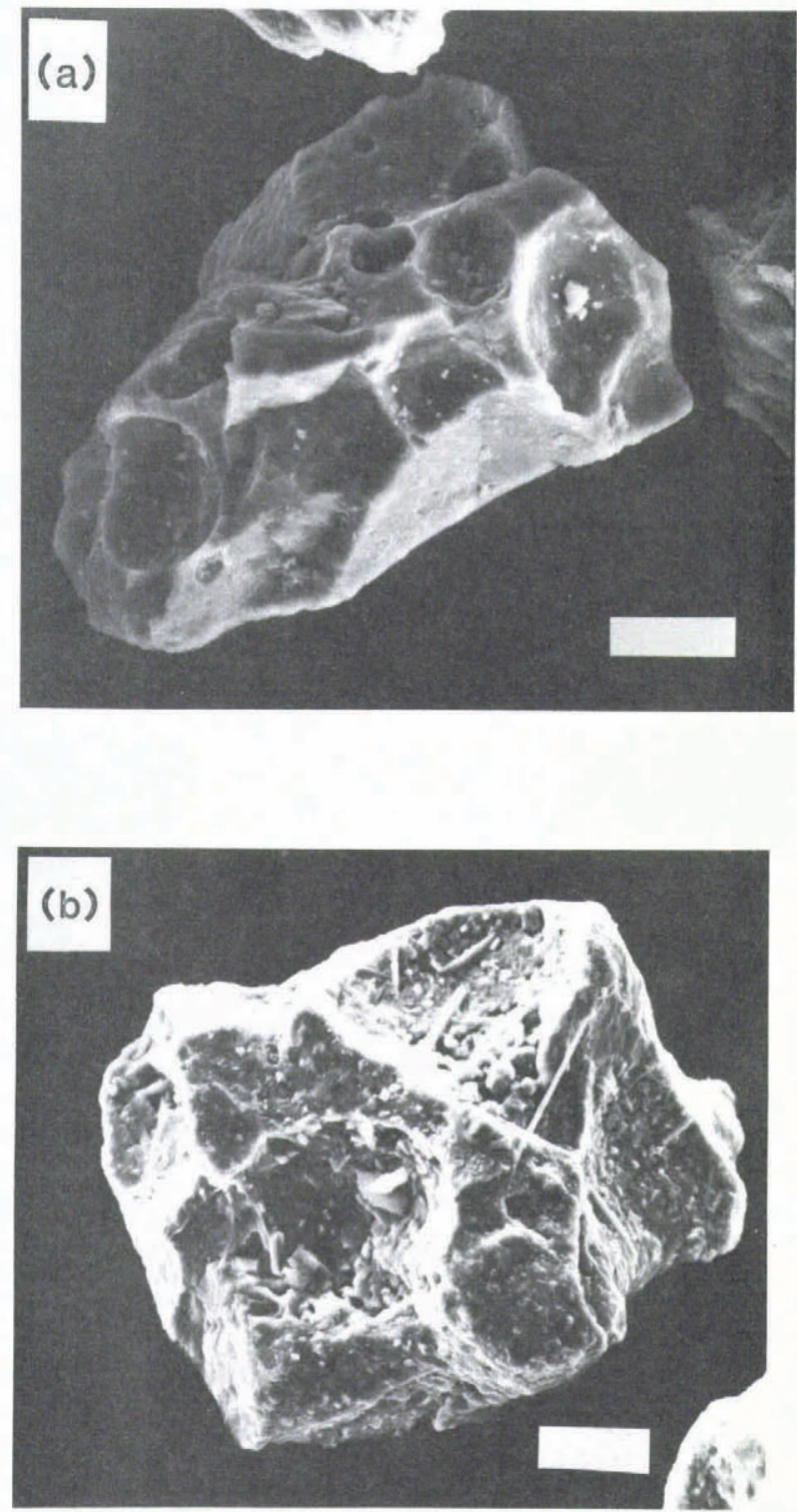

Fig.7. Scanning electron microphotographs of the volcanic glass shards from the dirt layer in the Allan Hills ice field. (a): A poorly vesicular glass shard with smooth surface. The scale is $50 \mu \mathrm{m}$. (b): A rectangular, poorly vesicular glass shard with a large amount of crystallites. The scale is $20 \mu \mathrm{m}$. amount of microlite and crystallite, and show rough-walled, rectangular or polygonal shapes (Fig.7).

Plagioclase, titanaugite, olivine, kaersutite, rhönite and titanomagnetite are observed under the microscope. Titanaugite is euhedral to subhedral, and shows faint pleochroism of light purplish-brown. Small grains of olivine occur in some glass shards as microlites, which alter into iddingsite with intense pleochroism, reddish-brown to pale orange. Kaersutite is commonly isolated, relatively coarse-grained, and euhedral to subhedral, and shows distinct pleochroism, brown to light brown. Rhönite occurs with titanaugite and shows strong pleochroism, dark brown to light brown.

\section{CHEMICAL COMPOSITION}

Major element compositions of the glass shards and the crystal fragments from each of the dirt layers from the Yamato Mountains and the Allan Hills regions were analyzed by electron probe microanalyser at the National Institute of Polar Research. The samples are tentatively named the Yamato ash and the Allan ash, respectively.

5.1. Glass shards

Chemical compositions of glass shards in tephra layers may indicate the nature of the rock suite, because they correspond to the liquid compositions of the source magma. Table II lists the average chemical composition of the glass shards in both ashes. The compositions of glass shards in the Yamato ash are relatively uniform, whereas those in the Allan ash are more or less dispersed.

As shown in the $\mathrm{Na}_{2} \mathrm{O}+\mathrm{K}_{2} \mathrm{O}$ versus $\mathrm{SiO}_{2}$ diagram (Fig.8), the glass shards of the Yamato ash are non-alkaline, whereas those of the Allan ash are alkaline. Selected analyses of the Cenozoic volcanic rocks from Antarctica are also plotted in this diagram. They are classified into two volcanic provinces: (1) the alkaline province of Byrd Land and Victoria Land, and (2) the non-alkaline province of the South Shetland Islands (high-alumina basalt series rich in $\mathrm{Na}_{2} \mathrm{O}$ ) and the South Sandwich Islands (low-alkali tholeiite series) (Katsui 1972, González-Ferrán and Vergara 1972 , González-Ferrán 1982). Sub-Antarctic islands such as Heard Island are comprised of alkaline rocks.

Volcanic rocks of the South Sandwich Islands are characterized by iron enrichment in the middle stage of differentiation of the tholeiitic series. As shown in the $\mathrm{Na}_{2} \mathrm{O}+\mathrm{K}_{2} \mathrm{O}$ - total $\mathrm{FeO}-\mathrm{MgO}$ diagram (Fig.9), the glass shards of the Yamato ash are plotted within the field of the South Sandwich Islands. The glass shards of the Yamato ash have low $\mathrm{TiO}_{2}$ contents and are not markedly enriched in total FeO. Accordingly, it is concluded that the glass shards of the Yamato ash have the distinctive feature of the island arc tholeiite defined by Jakes and Gill (1970). These features are similar to those of the rocks from the South Sandwich Islands. According to Baker (1976), these volcanic islands are dominated by basalt and basaltic andesite of island arc tholeiite composition. Among the South Sandwich Islands, Bellingshausen Island has probably developed in very recent times (Baker 1978). The composition of the less porphyritic basaltic andesite from this island is similar to that of the glass shards of the Yamato ash (Table II).

On the other hand, the glass shards of the Allan ash have the features of the alkaline rock series. Occurrence of the Cenozoic alkaline volcanic rocks are widely scattered throughout Byrd and Victoria lands. It is unlikely that their compositions show consistent areal variation. Therefore, only a representative rock, a trachybasalt from Ross Island (Goldich and others 1975), which has a similar composition to the glass shards of the Allan ash, is presented in Table II for comparison.

\subsection{Crystal fragments}

Pyroxene occurs in both ashes, and subcalcic augite in the Yamato ash has a similar composition to that of the South Sandwich Islands (Katsushima and others 1984). On the other hand, titanaugite, which is characteristic of alkaline rocks, is found in the Allan ash. In the Allan ash, kaersutite (titan-rich amphibole) and rhönite are observed (Table III). Occurrence of rhönite in basanite has been reported from the McMurdo Volcanic Group (Kyle and Price 1975). Table IV presents compositions of the mineral fragments in the Yamato and the Allan ashes. For 
TABLE II. AVERAGE CHEMICAL ANALYSES OF VOLCANIC GLASS SHARDS IN THE YAMATO AND THE ALLAN ASHES, AND COMPARATIVE ANALYSES OF VOLCANIC ROCKS FROM BELLINGSHAUSEN AND ROSS ISLANDS (BI: Basaltic andesite from Bellinghausen Island (Baker 1978), RI: Trachybasalt from Ross Island (Goldich and others 1975), n: number of individual analyses, $\sigma$ : standard deviation)

\begin{tabular}{|c|c|c|c|c|}
\hline Locality & Yamato ash & Allan ash & BI & RI \\
\hline & $n=14 \quad\left(\sigma_{n}\right)$ & $n=12 \quad\left(\sigma_{n}\right)$ & & \\
\hline $\mathrm{SiO}_{2}$ & $57.92(0.71)$ & $44.23(2.25)$ & 56.98 & 44.6 \\
\hline $\mathrm{TiO}_{2}$ & $1.00(0.09)$ & $3.76(0.47)$ & 0.91 & 3.46 \\
\hline $\mathrm{Al}_{2} \mathrm{O}_{3}$ & $13.98(0.82)$ & $16.29(1.37)$ & 16.14 & 16.9 \\
\hline $\mathrm{Cr}_{2} \mathrm{O}_{3}$ & $0.01 \quad(0.01)$ & $0.01(0.01)$ & - & - \\
\hline $\mathrm{FeO}^{*}$ & $11.03(0.44)$ & $10.19(0.78)$ & 10.59 & 10.7 \\
\hline $\mathrm{MnO}$ & $0.23(0.07)$ & $0.22(0.06)$ & 0.18 & 0.22 \\
\hline $\mathrm{MgO}$ & $2.81(0.37)$ & $4.06(1.02)$ & 2.80 & 3.78 \\
\hline $\mathrm{CaO}$ & $7.57(0.25)$ & $9.91(2.37)$ & 8.32 & 9.44 \\
\hline $\mathrm{Na}_{2} \mathrm{O}$ & $2.71(0.25)$ & $4.29(0.86)$ & 3.44 & 5.37 \\
\hline $\mathrm{K}_{2} \mathrm{O}$ & $0.39(0.06)$ & $2.95(0.50)$ & 0.60 & 2.01 \\
\hline $\mathrm{P}_{2} \mathrm{O}_{5}$ & $0.12(0.07)$ & $1.57(0.24)$ & 0.12 & 1.39 \\
\hline $\mathrm{NiO}$ & $0.05(0.05)$ & $0.03(0.03)$ & - & - \\
\hline Others & - & - & 0.16 & 0.44 \\
\hline Total & 97.82 & 97.51 & 100.24 & 98.3 \\
\hline \multicolumn{5}{|c|}{ CIPW norms (wt \%) } \\
\hline Q & 16.15 & - & 9.21 & - \\
\hline or & 2.29 & 17.44 & 3.55 & 11.88 \\
\hline$a b$ & 22.95 & 10.97 & 29.11 & 15.80 \\
\hline an & 24.83 & 16.48 & 26.83 & 16.07 \\
\hline ne & - & 13.72 & - & 16.06 \\
\hline $\mathrm{di}$ & 10.12 & 18.52 & 11.59 & 18.03 \\
\hline hy & 17.30 & - & 15.89 & - \\
\hline ol & - & 7.75 & - & 8.34 \\
\hline $\mathrm{mt}$ & 2.12 & 1.95 & 2.03 & 2.05 \\
\hline $\mathrm{cm}$ & 0.01 & 0.01 & - & - \\
\hline il & 1.90 & 7.15 & 1.73 & 6.57 \\
\hline ap & 0.28 & 3.64 & 0.28 & 3.22 \\
\hline Total & 97.95 & 97.63 & 100.22 & 98.02 \\
\hline
\end{tabular}

* $\mathrm{FeO}=$ total $\mathrm{Fe}$ as $\mathrm{FeO}$.

** For norm calculations, $\mathrm{Fe}_{2} \mathrm{O}_{3}$ standardized at $0.15 \times \mathrm{FeO}$. 


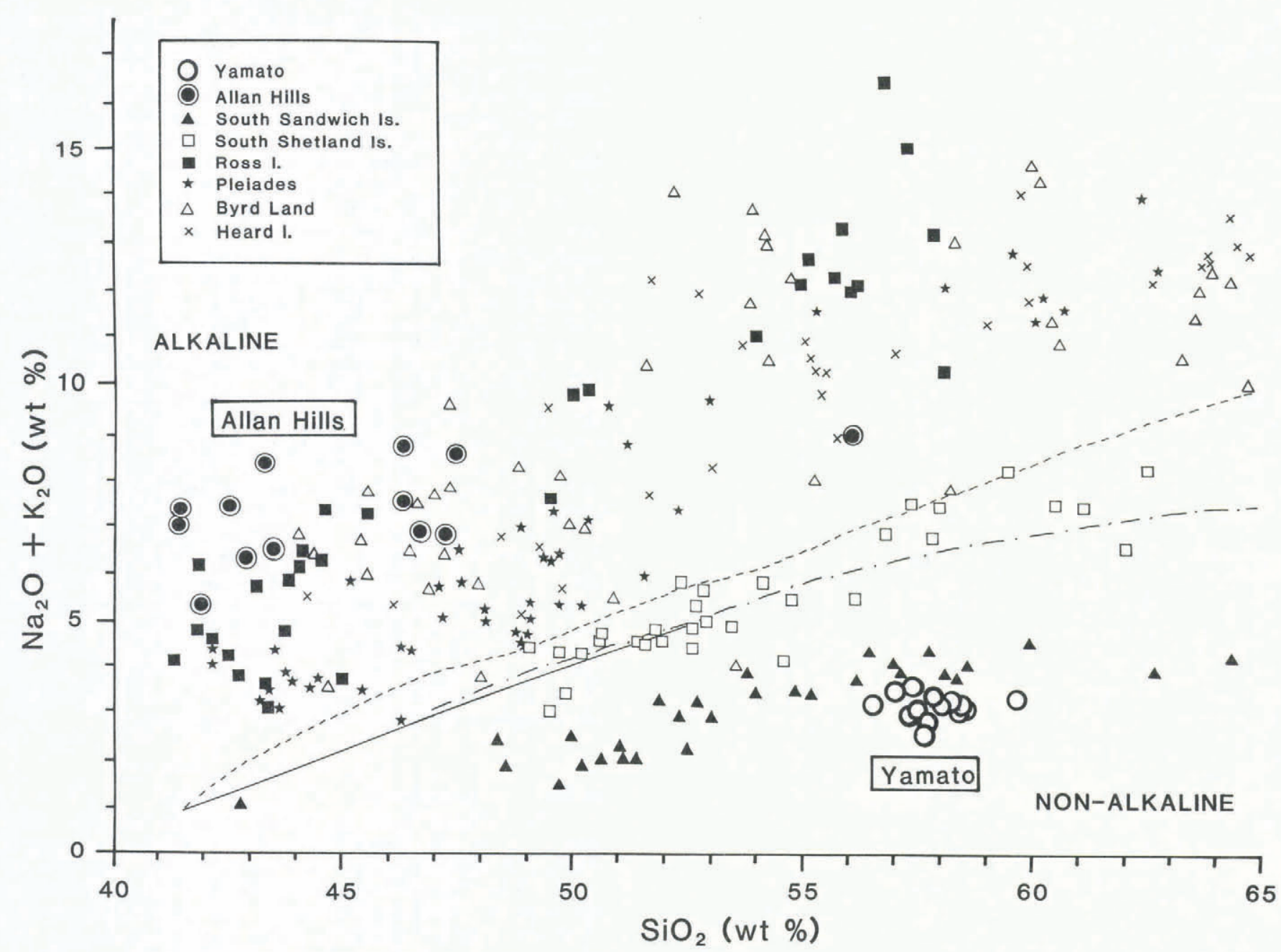

Fig.8. $\mathrm{SiO}_{2}-\mathrm{Na}_{2} \mathrm{O}+\mathrm{K}_{2} \mathrm{O}$ diagram of analyzed glass shards in the Yamato ash and the Allan ash (Yamato: average composition of glass shards in the Yamato ash. Allan Hills: average composition of those in the Allan ash). Shown for comparison are compositions of the Cenozoic volcanic rocks from the South Sandwich Islands (Baker 1978), the South Shetland Islands (González-Ferrán and Katsui 1970, Weaver and others 1982), Ross Island (Goldich and others 1975), Pleiades (Kyle 1982), Byrd Land (González-Ferrán and Vergara 1972), and Heard Island (Stephenson 1972). The boundaries between alkaline and non-alkaline fields are shown by solid (Macdonald and Katsura 1964), chain (Miyashiro 1973) and broken lines (González-Ferrán 1982).

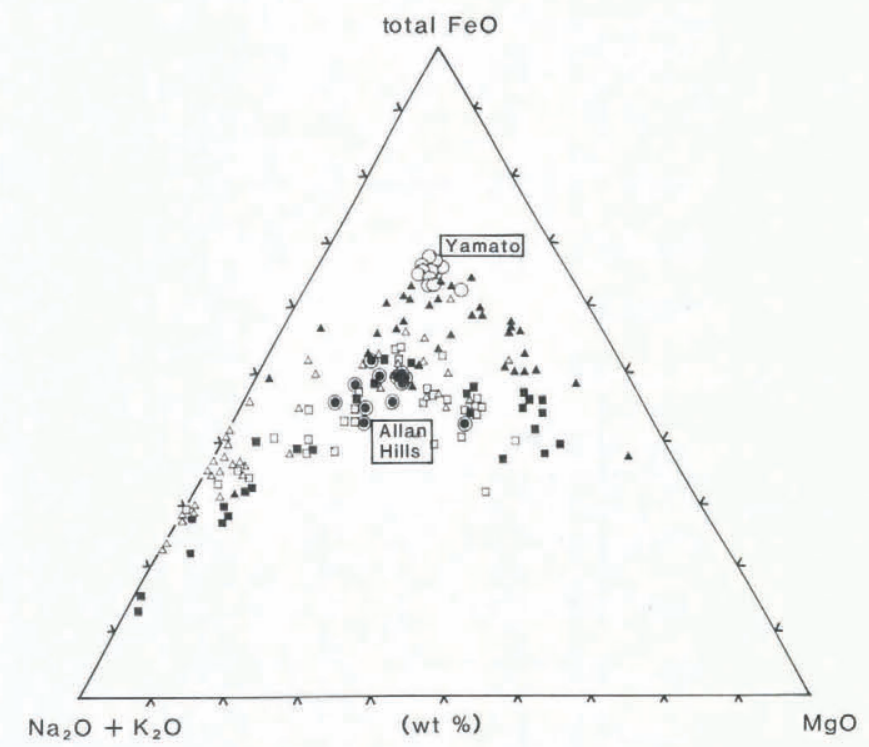

Fig.9. $\mathrm{Na}_{2} \mathrm{O}+\mathrm{K}_{2} \mathrm{O}-$ total $\mathrm{FeO}-\mathrm{MgO}$ diagram of analyzed glass shards in the Yamato ash and the Allan ash. Shown for comparison are compositions of the Cenozoic volcanic rocks from Antarctica. Legends and references are the same in Figure 8. comparison, those of the basaltic andesite from Bellingshausen Island and trachybasalt from Ross Island are also listed.

\section{DISCUSSION}

As a result of microscopic investigations, the constituent fragments of the dirt layers exposed in the Yamato Mountains and the Allan Hills regions are well-sorted and composed mainly of volcanic glass shards. The chemical compositions of the glass shards are relatively uniform in each layer, but differ markedly between both dirt layers. The mineral assemblages and chemical compositions of the crystal fragments in both layers are compatible with the compositions of the respective glass shards. No foreign fragments derived from the basement rocks can be observed. Therefore, it is suggested that each of the dirt layers represents a single fall unit of tephra which precipitated on the surface of the ice sheet.

Major element chemistry of the glass shards and the composition of the mineral fragments in the dirt layers indicate that the Yamato ash has characteristics of the island arc tholeiite series, whereas the Allan ash has those of the alkaline rock series. These compositional features make it possible to infer that their source regions, with reference to the Quaternary petrographic province, were in and around Antarctica. As described earlier, the Yamato ash is correlated with basaltic andesite from the South Sandwich Islands. Basaltic andesite of the low-alkali tholeiite of island arc type has not been reported around Antarctica except for 
TABLE III. CHEMICAL ANALYSES OF CRYSTAL FRAGMENTS IN THE ALLAN ASH

\begin{tabular}{|c|c|c|c|}
\hline & Titanaugite & Kaersutite & Rhönite \\
\hline $\mathrm{SiO}_{2}$ & 45.10 & 38.59 & 23.75 \\
\hline $\mathrm{TiO}_{2}$ & 3.99 & 5.43 & 12.00 \\
\hline $\mathrm{Al}_{2} \mathrm{O}_{3}$ & 7.22 & 14.14 & 16.72 \\
\hline $\mathrm{Cr}_{2} \mathrm{O}_{3}$ & 0.01 & 0.00 & 0.00 \\
\hline $\mathrm{FeO}^{*}$ & 7.20 & 11.19 & 20.67 \\
\hline $\mathrm{MnO}$ & 0.11 & 0.14 & 0.27 \\
\hline $\mathrm{MgO}$ & 12.71 & 12.10 & 12.67 \\
\hline $\mathrm{CaO}$ & 22.94 & 11.58 & 11.24 \\
\hline $\mathrm{Na}_{2} \mathrm{O}$ & 0.46 & 2.40 & 1.11 \\
\hline $\mathrm{K}_{2} \mathrm{O}$ & 0.02 & 1.85 & 0.00 \\
\hline \multirow[t]{2}{*}{ Total } & 99.76 & 97.42 & 98.43 \\
\hline & $\mathrm{O}=6$ & $\mathrm{O}=23$ & $\mathrm{O}=20$ \\
\hline $\mathrm{Si}$ & 1.701 & 5.771 & 3.284 \\
\hline $\mathrm{Ti}$ & 0.113 & 0.610 & 1.249 \\
\hline Al & 0.321 & 2.493 & 2.725 \\
\hline $\mathrm{Cr}$ & 0.000 & 0.000 & 0.000 \\
\hline $\mathrm{Fe}$ & 0.227 & 1.400 & 2.390 \\
\hline $\mathrm{Mn}$ & 0.004 & 0.017 & 0.031 \\
\hline $\mathrm{Mg}$ & 0.715 & 2.697 & 2.612 \\
\hline $\mathrm{Ca}$ & 0.927 & 1.855 & 1.666 \\
\hline $\mathrm{Na}$ & 0.033 & 0.696 & 0.297 \\
\hline K & 0.001 & 0.353 & 0.000 \\
\hline
\end{tabular}

${ }^{*} \mathrm{FeO}=$ total $\mathrm{Fe}$ as $\mathrm{FeO}$ the South Sandwich Islands. Therefore, it is inferred that the Yamato ash has been derived from a volcano of the South Sandwich Islands, which are about $3000 \mathrm{~km}$ away from the Yamato Mountains. This is also supported by the results of grain-size analyses and atmospheric transportation of volcanic glass on the Yamato ash (Nishio and others 1984). Tholeiitic tephra such as the Yamato ash has not been reported before in Antarctic ice sheets.

On the other hand, alkaline tephras have been described in several other areas of Antarctica. It has been suggested that the tephras found in the Byrd and the Dome $\mathrm{C}$ ice cores were derived from Mt Takahe in Byrd Land, as evidenced by their chemical similarity (Kyle and Jezek 1978, Kyle and others 1981). An example of tephra exposed on the surface of bare ice was reported from Skelton Nevé and Kempe Glacier, south Victoria Land by Keys and others (1977), who deduced from grain-size composition, age and other features that the tephra originated from some volcano in the Royal Society Range-Koettlitz Glacier area.

Quaternary alkalic volcanic rocks are widely distributed throughout Byrd and Victoria lands including the McMurdo Sound region. The chemical feature of each volcano is, however, not sufficient to be realized. Therefore, at present it is difficult to specify which volcano yielded the Allan ash. As shown in Figure 5, the coarse grain size of the Allan ash compared with the Yamato ash may indicate the source volcano to be not so distant as that of the latter (Nishio and others 1984). Accordingly, the Allan ash may have been supplied from some young volcano of the McMurdo Volcanic Group, though further studies are needed before the source volcano is specified.

\section{ACKNOWLEDGEMENT}

The authors wish to thank members of the 23rd Japanese Antarctic Research Expedition, led by Professor T Hoshiai, National Institute of Polar Research, and also to express their sincere thanks to Professor Y Katsui and Dr S Miyashita of Hokkaido University for critical discussions. They are indebted to $\mathrm{Dr} \mathrm{K}$ Yanai and $\mathrm{Mr} \mathrm{H}$ Kojima for many useful suggestions and permitting us to use the electron probe microanalyser at the National Institute of

TABLE IV. CRYSTAL FRAGMENTS IN THE YAMATO AND THE ALLAN ASHES AND CONSTITUENT MINERALS IN VOLCANIC ROCKS FROM BELLINGSHAUSEN AND ROSS ISLANDS

\begin{tabular}{|c|c|c|}
\hline & Yamato ash & $\begin{array}{l}\text { Basaltic andesite* } \\
\text { (Bellingshausen Island) }\end{array}$ \\
\hline Plagioclase & An $59-79$ & An $65-85$ \\
\hline Clinopyroxene & Augite - subcalcic augite & Augite - subcalcic augite \\
\hline Orthopyroxene & Bronzite - hypersthene & Bronzite - hypersthene \\
\hline Opaque mineral & Magnetite & Magnetite \\
\hline & Allan ash & $\begin{array}{l}\text { Trachybasalt** } \\
\text { (Ross Island) }\end{array}$ \\
\hline Plagioclase & An $59-70$ & Labradorite \\
\hline Clinopyroxene & Titanaugite & Titaniferous augite \\
\hline Amphibole & Kaesutite & Kaersutite \\
\hline Others & $\begin{array}{l}\text { Olivine, rhönite, } \\
\text { titanomagnetite }\end{array}$ & $\begin{array}{l}\text { Olivine, apatite, } \\
\text { opaque mineral }\end{array}$ \\
\hline
\end{tabular}


Polar Research. They also make grateful acknowledgement to Professor A Higashi of Hokkaido University for constant encouragement of this study.

\section{REFERENCES}

Baker P E 1976 Volcanism and plate tectonics in the Antarctic Peninsula and Scotia arc. In González-Ferrán O (ed) Proceedings of the symposium on "Andean and Antarctic volcanology problems" (Santiago, Chile, September 1974). Rome, International Association of Volcanology and Chemistry of the Earth's Interior: 347-356

Baker P E 1978 The South Sandwich Islands: III. Petrology of the volcanic rocks. British Antarctic Survey. Scientific Reports 93: 1-34

Carey S N, Sigurdsson H 1982 Influence of particle aggregation on deposition of distal tephra from the May 18, 1980, eruption of Mount St. Helens volcano. Journal of Geophysical Research 87(B8): 7061-7072

Cornell W, Carey S, Sigurdsson H 1983 Computer simulation of transport and deposition of the Campanian $\mathrm{Y}-5$ ash. Journal of Volcanology and Geothermal Research 17: 89-109

Goldich S S, Treves S B, Suhr N H, Stuckless J S 1975 Geochemistry of the Cenozoic volcanic rocks of Ross Island and vicinity, Antarctica. Journal of Geology 83(4): 415-435

González-Ferrán O 1982 The Antarctic Cenozoic volcanic provinces and their implications in plate tectonic processes. In Craddock C (ed) Antarctic geoscience. Symposium on Antarctic geology and geophysics, Madison, Wisconsin, U.S.A., August 22-27, 1977. Madison, University of Wisconsin Press: 687-694

González-Ferrán O, Katsui Y 1970 Estudio integral del volcanismo Cenozoico superior de la Islas Shetland del Sur, Antártica. Instituto Antártico Chileno. Serie Cientifica 1(2): $123-174$

González-Ferrán O, Vergara M 1972 Post-Miocene volcanic petrographic provinces of West Antarctica and their relation to the southern Andes of South America. In Adie R J (ed) Antarctic geology and geophysics. Symposium on Antarctic geology and solid earth geophysics, Oslo, 6-15 August 1970. Olso, Universitetsforlaget: 187-195

Gow A J 1963 The inner structure of the Ross Ice Shelf at Little America V, Antarctica, as revealed by deep core drilling. International Association of Scientific Hydrology Publication 61 (General Assembly of Berkeley 1963 - Snow and Ice): $272-284$

Gow A J, Williamson T 1971 Volcanic ash in the Antarctic ice sheet and its possible climatic implications. Earth and Planetary Science Letters 13(1): 210-218

Jakes P, Gill J 1970 Rare earth elements and the island are tholeiitic series. Earth and Planetary Science Letters 9: $17-28$

Katsui Y 1972 Late Cenozoic petrographic provinces of the volcanic rocks from the Andes to Antarctica. In Adie $\mathrm{R}$ (ed) Antarctic geology and geophysics. Symposium on Antarctic geology and solid earth geophysics, Oslo, 6-15 August 1970. Oslo, Universitetsforlaget: 181-185

Katsushima T, Nishio F, Ohmae H, Ishikawa $M$, Takahashi S 1984 Composition of dirt layers in the bare ice areas near the Yamato Mountains in Queen Maud Land and the Allan Hills in Victoria Land, Antarctica. Memoirs of National Institute of Polar Research. Special Issue 34: 174-187

Keys J R, Anderton P W, Kyle P R 1977 Tephra and debris layers in the Skelton Névé and Kempe Glacier, south Victoria Land, Antarctica. New Zealand Journal of Geology and Geophysics 20(5): 971-1002

King E A, Wagstaff J 1980 Search for cometary dust in the Antarctic ice. Antarctic Journal of the United States 15(5): 78-79

Kyle P R 1982 Volcanic geology of the Pleiades, northern Victoria Land, Antarctica. In Craddock C (ed) Antarctic geoscience. Symposium on Antarctic geology and geophysics, Madison, Wisconsin, U.S.A., August 22-27, 1977. Madison, University of Wisconsin Press: 747-754

Kyle P R, Jezek P A 1978 Compositions of three tephra layers from the Byrd station ice core, Antarctica. Journal of Volcanology and Geothermal Research 4: 225-232
Kyle P R, Price R C 1975 Occurrences of rhönite in alkalic lavas of the McMurdo Volcanic Group, Antarctica, and Dunedin volcano, New Zealand. American Mineralogist 60: 722-725

Kyle P R, Jezek P A, Mosley-Thompson E, Thompson L G 1981 Tephra layers in the Byrd station ice core and the Dome C ice core, Antarctica and their climatic importance. Journal of Volcanology and Geothermal Research. 11(1): 29-39

Kyle P R, Palais J, Delmas R 1982 The volcanic record of Antarctic ice cores: preliminary results and potential for future investigations. Annals of Glaciology 3: 172-177

Macdonald G A, Katsura T 1964 Chemical composition of Hawaiian lavas. Journal of Petrology 5: 82-133

Miyashiro A 1973 The Troodos ophiolitic complex was probably formed in an island arc. Earth and Planetary Science Letters 19: 218-224

Naruse R 1978 Surface flow and strain of the ice sheet measured by a triangulation chain in Mizuho Plateau. Memoirs of National Institute of Polar Research. Special Issue 7: 198-226

Nishio F, Annexstad J O 1979 Glaciological survey in the bare ice area near the Allan Hills in Victoria Land, Antarctica. Memoirs of National Institute of Polar Research. Special Issue 15: 13-23

Nishio F, Annexstad J O 1980 Studies on the ice flow in the bare ice area near the Allan Hills in Victoria Land, Antarctica. Memoirs of National Institute of Polar Research. Special Issue 17: 1-13

Nishio F, Katsushima T, Ohmae H, Ishikawa M, Takahashi S 1984 Dirt layers and atmospheric transportation of volcanic glass in the bare ice areas near the Yamato Mountains in Queen Maud Land and the Allan Hills in Victoria Land, Antarctica. Memoirs of National Institute of Polar Reseach. Special Issue 34: 160-173

Stephenson P J 1972 Geochemistry of some Heard Island igneous rocks. In Adie $\mathrm{R} \mathrm{J}$ (ed) Antarctic geology and geophysics. Symposium on Antarctic geology and solid earth geophysics, Oslo, 6-15 August 1970. Oslo, Universitetsf orlaget: $793-801$

Weaver S D, Saunders A D, Tarney J 1982 Mesozoic-Cenozoic volcanism in the South Shetland Islands and the Antarctic Peninsula: geochemical nature and plate tectonic significance. In Craddock C (ed) Antarctic geoscience. Symposium on Antarctic geology and geophysics, Madison, Wisconsin, U.S.A., August 22-27, 1977. Madison, University of Wisconsin Press: 263-273

Yanai K 1981 Collection of Yamato meteorites in the 1979-1980 field season, Antarctica. Memoirs of National Institute of Polar Research. Special Issue 20: 1-8 